\title{
Tourism Innovation and Pandemic Compliance in a Lonesome Aegean Islet, after Regeneration of thousands Noninhabitant Islands into a Sustainable, Profitable Ecosystem and Hotel
}

\author{
ATHANASIONS Zisopoulos ${ }^{*}$, Nikos Kartalis ${ }^{\text {a }}$, Georgia Broni ${ }^{\text {a }}$ \\ ${ }^{a}$ International and European Economic Studies, Economic Faculty \\ University of Western Macedonia, Kozani, Greece \\ corresponding author emails: ZISOPOULOS.Athanasios.Dim@gmail.com
}

\section{ABSTRACT}

We work in the Aegean islet hotel-room environment a friendly design from scratch for many years with legislation, political, defense, and engineering developments. Pandemic triggered out our initial findings. As a curse threatens tourism and as a blessing, it reveals new unpreceded hospitality options. In this research paper, we outline some scientific proceeds like Coastline Paradox and investment opportunity. The Aegean Sea has several thousand islands without inhabitants and several million meters of coastline certifying the "Coastline Paradox". The fundamental concept of a guest room on an isolated tiny island is ecological vacations in the Aegean Sea, the marooning stranded in an islet vacation, the myth creation to attract guests, and the books and media coverage of the loneliness concept. The noninhabitant islands initially will be revitalized from deserted salinity virgin lands to beautiful paradises, with new flora and fauna, human living facilities, and optionally overnight sleeping space. A huge, city-size, modular ship with service boats formulate the Aegean Highway. All these workouts establish the Aegean Island resort hotel. All islets will be used as hotel rooms hosting various tourist and business activities. Finally, we face business concepts like COVID compliance, sovereignty, Aegean-wide services, and business realization options.

Keywords: Island tourism sustainability, Coastline Paradox, Tourism Innovation, levels of restoration, sustainable tourism, exclusivity, visitor experience

\section{Introduction}

\subsection{Concept summary}

There is a contentious scientific opinion, that development and sustainability are about preserving the environment as we took from previous generations. We have the right to improve drastically the environment in a sustainable methodology. Sometimes ecologist aficionados demand to preserve a tiny, deserted, salted islet without flora and fauna just for the shake of their beliefs. We strongly believe that in a lot of cases revitalization is the best solution for the environment and humanity. Our approach for planning and development comprises human behavior understanding, marketing, and promotion pseudo actions, zero eco productions business effort, sovereignty and law enforcement options, insurance advance modeling, eco-construction engineering, and preferential contracting through invention patents.

The guest room in an isolated tiny island is analyzed in all aspects: the temporospatial dimensions of the Aegean Sea, the marooning-stranded stay, the myth creation to attract guests, and the books and media coverage of the loneliness concept. A new business environment prescribed for primordial Pelasgian sea, hotel room-island naming, and general implementation details.

Initially, Hall (2013) defined the variations to upgrade coastal destinations and the capacity to diversify, at a national level, away from coastal dominance. Principles in Integrated Coastal Management (ICM) are described by Caffyn (2003) as Governance Capacities Images, culture, data collection, and
NGOs (Non-Government Organizations). The Anthropocene is a proposed term for a new phase in the history of both humanity and the Earth a geological epoch in which their respective forces intertwine on a planetary scale (Gren, 2014). We attempt to prove that the European way of life will preserve according to the Vice-President of the European Commission and designate for Protecting our European Way of Life (Schinas, 2019).

Sustainability in tourism is a key concern. Dickinson (2013), found a scope to improve green transport through understanding visitor practices, influence meanings associated with visitor travel and travel skills. Eijgelaar (2016), showed that Dutch consumers prefer a recognizable carbon label, similar to the EU energy. Kantenbacher (2019), used a novel method to assess the willingness of individuals to sacrifice holiday air travel relative to their willingness to make changes to their daily consumption patterns. We do not believe in absolute accuracy in any kind of Public opinion calculations. Our research focus on engineering proved zero eco-footprint, not in the marketing effort. Melissen, (2016) has shown the limited ability for academia to initiate the structural changes needed for sustainable development in tourism. Our research started as a COVID opportunity, it continued as an insurance modeling and it is now more a geoengineering experiment spreading around the Aegean having:

- Every noninhabitant island regains a role in local development.

- Most islands will be revitalized into Edem paradises. 
E-ISSN: 2469-6501

VOL: 7, ISSUE: 6

June/2021

http://dx.doi.org/10.33642/ijbass.v7n6p4

\section{(C) Center for Promoting Education and Research (CPER) USA}

Www.cpernet.org

- The rest islands will serve as green energy and production places.

- Every tiny island is a hotel room, a huge villa, or a resort facility

- Three low-speed ship platforms serve all these islands at least once per day.

- The platform itself is a full logistics and production unit.

Starting from Geography the Aegean-Pelasgian sea hosts for 5000 years now the global merchandising shipping; today one out of four ships are Greek (Un, 2020). The island resort only comes as a natural progression for such a naval history. Islands generally and Aegean islands do suffer from:

- local overdevelopment,

- population immigration, refugees,

- sea level rise,

- Mediterranean weather alteration, storm intensity, and frequency,

- overfishing,

- oil-based energy,

- over-development,

- freshwater reserves,
- flora and fauna degradation, loss of species,

- local inhabitant income incensement.

\subsection{The coastline Paradox}

Tourism definition is also about feelings and art. Emmons, (2017) selected Naylor's poem about the coastline paradox as a mathematical language metaphor and mathematics as content for poems. A year later the phenomenon known as the coastline paradox has been analyzed by two researchers. First Ciruelos, (2018) started from the circle that maximizes the area for a given perimeter came to a conclusion that determined the roundness of a figure by how close its ratio is to $4 \pi$. Countries generally have fractal-like perimeters (also known as borders), so they tend to be much longer than they seem to be. Then, Freksa (2018) demonstrated that the measured length of an unsmooth line depends on the granularity of the measuring device and that the formalization of real-world entities may introduce structural incompatibilities in the conceptualization of spatial entities. Recently Sammler (2020) referred to the Coastline Paradox as the length of a country's coastline will depend on the length of the ruler used. We leverage this illusion of coastline paradox to build a resort hotel line unparallel around the earth today.

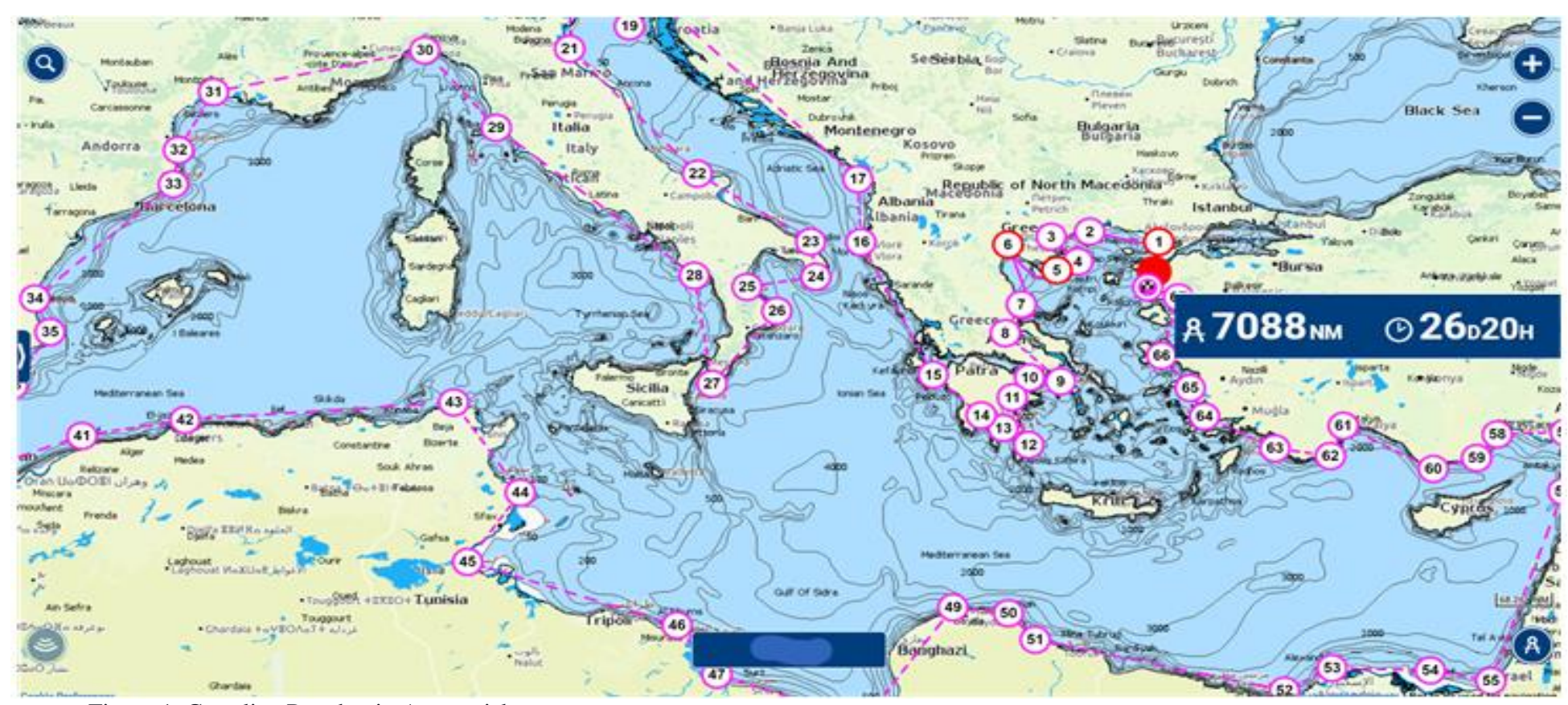

Figure 1, Coastline Paradox in Aegean islets resort

The coastline of mainland Greece along with that of the island's length is over $15.147 \mathrm{~km}$. (Coastial 2012). It is the largest coastline of any other country in the Mediterranean and it is the eleventh coastline in the global ranking. The 6126 Greek Islands coastline exceeds $10823 \mathrm{~km}$ according to more detailed Navy sources trying to solve the coastline paradox. From these islands' only a few have residents while the rest are noninhabitant with shepherds, fish farmers, fishermen, and hunters (Sailing, 2021).
For presentation, we calculated in a yachting website a Garmin geography map of the "travel" around the Mediterraneansea from pillars of Hercules and Ilusseus island to Israel and Alexandria. The seashore around the Meditetrannean was 7088 Nautical miles, a little more than the seaside beach accumulated for all the Aegean noninhabitant islands.

\subsection{Myth Creation and Tourism}


Myth creation shows significant successes recently. Gregory-Smith (2017) suggested that a good understanding of the tourism, organizational context, and the use of tailored, action-focused mechanisms are critical to achieving transformational outcomes in environmental interventions in cultural heritage organizations.

Higham (2013), interrogated the behavioral and psychological dimensions of tourist mobility consumption, the complexity of consumer decision-making and highlighted the climate responsiveness and environmental concern for tourism consumption. Ram, (2013) shown that happiness is integral to all stages of the tourist experience, recognized the role of happiness in sustainable tourism strategies and proposed a "three-gear" model of unsupportive tourist behavior. The travel to myth-related places vogue is recent. Nilsson (2018), contributed to expanding place, identity, and myth-related tourist destinations. Tourist destinations should not be seen as prearranged phenomena just waiting to be discovered and consumed. Another key issue in our research was effective policies to change behavior towards more sustainable tourism practices. Araña (2016) compared taxing emission levels against non-market green policies like environmental information labeling; emotional communication messages, and limiting time pressure marketing practices. Brockway (1998) suggests that tourists are rational calculation humans but also "animal spirits" that can better describe human behavior. Hall (2016), noted the need for attitude change by tourism researchers, as well as by governments, the industry, and tourists. Knowledge of political psychology and upstream social marketing by itself will not lead to worthwhile transitions.

Amoamo (2011) in Pacific British overseas territory studied the role of "myth-making" as a key determinant of a specialist rather than generalist mass tourism strategies with key objects in resiliency, durability, malleability, and persistence to create a sustainable tourism economy. Finally, Morgan (2017) rephrased another island myth with colonial past, feminine, and exotic soft primitivism.

\subsection{Marooning Cocooning vacations}

Mijuskovic (1981) complied double with myth creation and cocooning. In his "poem" is referred to the lonely route: the punishment of Prometheus; the humiliation of Achilles; the exile of Odysseus by Poseidon; the blindness of Oedipus; the entombment of Antigone. All this loneliness occurred around the primordial Pelasgian islands. After three thousand years of living in a noninhabitant modern Aegean island loneliness has various degrees. Types of loneliness counting up are:

- A deserted lonely island (0 guests)

- A person living alone in an isolated island (1 guest)

- Two lovers living their dream in a paradise island (2 guests)

- A family of mother, father, and children (3+ guests)
- A family reunion with (10+ guests)

Rudden (2011), facilitated to development of our tiny island hotel rooms defining the secret cocoon as "a sense of being in a reverie, alone, safe, but also in hiding". In Aegean resort the guest is drawn to his safe place, compulsively, frightened, and unable to reconnect to reality and others. Cochrane (2015) defined the social construction of wilderness and its relevance to Western attitudes towards conservation and tourism. An initial similarity of our Aegean myths concept studied by Siegel (2013) as a heritage in the Caribbean and the use of current socioeconomic demands, the unique legislative environments of independent island nations, and overseas possessions of developed countries.

\subsubsection{Whatever happens in Vegas, stays in Vegas}

To enhance the segregation in tourism thinking we remembered the more famous slogan in modern tourism marketing the classic American "What Happens in Vegas, Stays in Vegas". MacCannell (2012) faces tourism as a Moral Science. Far away from Vegas morality, we rephrase the slogan to describe better our hospitality nature. Of course, whatever happens on a tiny island, it stays there. There is no neighborhood, no visitors no peculiar personnel, only silent dolphins and birds.

The deserted-hidden island experience fulfills the specific psychological needs of a human person. Similar island situations are:

- Marooning

- Stranded in an island

- Cocooning with others.

Hospitality and leisure go together. An idyllic island with "me, myself and I" or "me and my love" was the beloved subject in the book, comics, TV, and game industry. In literature, upon these three a whole industry with thousands of titles and millions of fans is unfolded. Traditional books, comics, motion pictures, TV series, games, and sites titles have been analyzed and the world mysteries and history were in these title with repeating words like:

"Death, Millionaire, Rock Star, Marquis, a beer, scouts, Maverick, Naked, marine, Manhattan, Niger, Scavenger, Moscow, Africa, Nova Scotia, Miami, monkey, Atoll, forest, Arctic, Caribbean, Andromeda, Mercury, Mars, Space, Eden, planet Tau, under Sea Wreck, Pirate coast" and a lot more Of course, all these books do not take place on an island, a number of them use marooning as a drama metaphor, which denotes the same human necessity.

\section{Materials and Methods}

Since Myth manipulation is crucial for our effort we necessarily focus on films, books, fairy tales, games, and similar realizations. Loneliness' viable tourism development initial definition phases include:

- Temporospatial placement, analysis, strengthening, and entrenching

- Islet-hotel room identification. 
- A new type of low-speed vessel and super Highway. is; travel cost and duration, European food and taste, common

- Island regeneration from a desert island into history, and ethics.

paradise.

\subsection{Primordial Pelasgian Sea}

The distributed islet hotel rooms could be applicable anywhere around the globe world. The most similar effort is Fiji Islands.

Scheyvens (2008) found problems with unskilled

The need to offer island tourism is more crucial today due to global warming (Jarratt, 2020; Mayer, 2018; Nyaupane, 2009; Ateljevic, 2020) and temperature increase in the Mediterranean Sea (Rutty, 2010). The problem here is not like Fuji, Maldives, and greater Miami, only a minor environmental people, lack of resources for the 'tiny' and 'fragile' islands. today. Our project superiority over Fiji Islands for European tourists

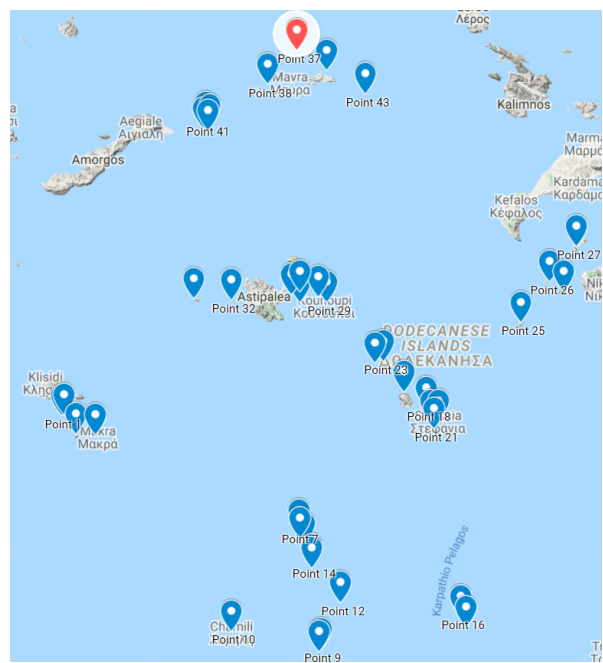

Figure 2, Forty-three (43) noninhabitant island in Cyclades

The map indicates only the 43 bigger islands in the central Cyclades Archipelago from the 2000 noninhabitant islands having initial eligibility for revitalization and tourism exploitation. Stevenson (2013) described a similar regeneration-restoration with Complex Adaptive Systems (CAS) our case is far more complex and patent preferential rights-oriented.

\subsection{Hotel rooms, villas, and resort facilities on Aegean islands}

\subsubsection{Hotel room names}

The hotel territory is under Greco-Roman civilization for 4500 years. This is not depicted in the island's toponyms mostly due to lack of imagination, no tourism around, poverty, and low-value properties. (Papalas, 2013; Kowalski, 2012)
A beautiful map of Aegean islets with meaningful to the global tourist names calms the eyes of the hotel guest. Once we start for another millennium of history we need new names. New islet names and the compo ships guidelines selection eligibility could be:

- The Ancient Greco Romano names must be faintly meaningful.

- There will be only International Names No Greek or Roman translation.

-There is the possibility of name sponsorship from selected companies or authorities.

-Naming could be arranged in thematic history areas.

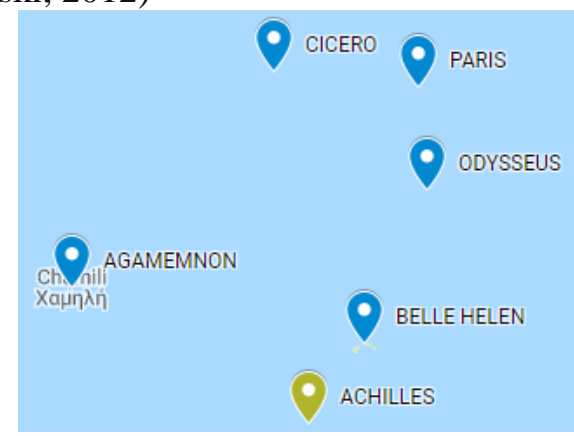

Figure 3, HOMERUS Trojan War islets.

TempoSpatial investment placement is crucial. An telling adopted García Romero (2013) research where the islet named from the famous Latin writer Cicero. Our story- Latin writer Cicero refers to a passage from a lost work by the 
Platonic philosopher Heraclides Ponticus (4 B.C.) in his work Tusculan disputations (5.3.8-9). There the wise Pythagoras is asked 'what a philosopher is. The passage continues about wisdom and 'philosopher' definition. Pythagor was an Ionian philosopher that influenced Plato, Aristoteles, and all Western philosophy. Gembillo, 2007; and thousands of others every year). Pythagoras's name will be given to a wide area near the Mathematician island of SAMOS according to our marketing strategy.

\subsubsection{Room-island layout}

The integrated unified "hotel" room preliminary description incorporates all-island support settings: Islands, ships, boats, kitchens, drones, personnel; All particular offer to the visitor an unpreceded leisure experience. Only for the presentation concept, we converted an islet to a single hotel room or apartment. The islet remains a natural or improved sustainable natural paradise with trees, beaches, birds, fishes, waters. The room, in a sustainable way, could have nothing or all of the modern facilities water, bath, electricity, internet, and hundreds more upon selection. We currently develop a logistics technology patent for an, appropriately sized container that is prepared every day in the facility ship to be dispatched to the island through the Aegean highway. The semi-automatic container primarily delivers to room food, meals, electricity, towels but we intend to use it as a "reconfiguration" of the whole room to various levels from 0 to 7 start hotel room. The room island layout selection follows all environmental technologies presented in this research and more according to availability and cost. There is very limited literature for special hotel rooms and much more simple (Bruwer 2012) F.

\subsubsection{Sweet lonely-ness normal room-villa}

Tourism and history are rewritten in various aspects creating new sustainable assets only by investing money. To create profit from the hotel lonely room it concerns a more difficult task. Our high cost and profit are paid by our guests; therefore, we only have to offer a service, a leisure opportunity, or a heal from illusions. One of their illusions or alleged illusions is the time-space illusion.

The "Garden of Eden Illusion" involves a time pause, nothing changes, is no progression, no frustration, no losses, and no passion (Steiner, 2018). Although it concerns Biblebased research the findings could be not accepted by East Catholic Church. The hidden islet room would help partially with all differentiated Narcissistic Perversions, Oedipal Perversions, and Romantic Perversions. The mechanism for this exceeds the purposes of our research, our primitive thoughts of the time on a tiny island are byzantine time, daylight time, and everyday lifetime.

Byzantine time adoption (Georgios,2019), where modified Time Series approach divides equally the day into 24 hours. In city normal life. with all these technologies, lights, noises, gadgets we cannot realize the daylight differences where astronomical dusk, nautical dusk, civil dusk occur. In a tiny islet guest room, one moment with the duration of a few seconds, we span it in an hour. They proudly enjoying our unique nautical twilight.

In a tiny islet guest room, one moment with the duration of a few seconds, we span it in an hour. They proudly enjoying our unique nautical twilight. Another time very much used in our daily life is Epoch, ISO time and Microsoft. Although the differences are not understandable by the human all three times increasingly dominate our everyday life. Due to the dominance of the isolated island, epoch time there is not crucial or not existed anymore. There are more priorities to concern about.

The space problem is not exactly a delusion but rather a modern disordering arrythmia or supposed space perception. Sedgwick and Gillam (2017) described forms of information that could use to give the hotel guest a different space definition: surface as a reference, local and remote processing, compression and crop, geometrical structures and boundaries, and surfaces. There are many similar studies but they will be investigated in the medical-room island below. As a general approach, we only keep that people in modern society live in their own very restricted dimensions and an island with specific borderlines to nowhere could help them.

Human spaced re-dimensioning in the limitation of a detached islet is good for the mental health either as an enjoyable leisure vacation or if the thing is going wrong as an interesting adventure making life interesting.

\subsection{The Aegean Highway}

\subsubsection{DeucalioNoachian Ark (DNA)}

Science Fiction and Motion Pictures from Jules Verne to Kevin Costner historically pave the way for future science and business proceeds. Universal Picture's most expensive film of all times time was "WaterWorld" an American postapocalypse film, based on s based on Rader's original play written back in 1985. (Reynolds, 1995; Focus, 2017).

As its title explains, the film describes the world after the second Deluge of Deucalion or the Noachian flood. Therefore, we have the acronym Deucalion-Noachian Ark, DNA as the collative interconnection of all islands in the hotel. Thirty years ago, the film set the standards of climate change while science was measuring, calculating, and navel-gazing. Elements from the film will be implemented as a superset for the Aegean Hotel:

-The floating ever traveling around the globe cityvessel.

- The intimidation for sustainable development.

-The trimaran with the sailing

The domains of transport and tourism exist and operate together and apart from one another but there is an urgent need to move away from our current "modus operandi" for both transport and tourism (Hopkins,2020). Another researcher (Peeters, 2013) examined the behavioral approach to attract hotel customers and the use of a long-term global 


\section{(C) Center for Promoting Education and Research (CPER) USA}

www.cpernet.org

tourism transport model for private and public sector tourism policymakers. We do not agree in his context that "technology is unlikely to reduce tourism transport's impact on climate change sufficiently to avoid serious dangers; behavioral change is necessary". An invention patent line (Zisopoulos, $2020 ; 1 \& 2 \& 3)$, associated construction and productions is a sustainable and financial engineering schema, could solve all associated problems.

A more sophisticated analysis by Smith (2019) found the scope to improve sustainable transport provision at destinations through understanding visitor practices, associated travel skills, and preferences for the needs of some visitors more than others. Tomej (2020) found that in rural areas, tourist attractions are spatially scattered and public transport is a more sustainable option for mobility.

The main disadvantage of Aegean entrepreneurship is transport and travel. There are high-tech solutions to enhance this but not at the level of future sustainability standards. The solution we choose is a huge floating platform with design specifications:

- A ship, many interconnected ships, a platform, and associated ships.

- Living space for more than ten thousand inhabitants and on-ship offshore productions space.

- Very low speed cruising speed for environmental reasons.

- Capability for some helicopters, motorboat mooring, sailors, and more

- All logistics integrated services in a global international setting.

\subsubsection{Unsinkable Vessel Invention Patent}

Sustainable development levels follow an upstream step according to funds a technology availability:

- Zero environmental pollution.

- Action to retain the environment untouched.

- Restoration up to a better living environment.

Any ship in the hotel area must be unsinkable for environmental reasons and traveler security. The tourist, when he travels abroad, feels insecure about everything. An unsinkable ship stimulates the tourist's ability to enjoy his vacations especially being in "undiscovered waters" conceptually and literally.
Any ship in the hotel area must be unsinkable for environmental reasons and traveler security. The tourist, when he travels abroad, feels insecure about everything. An unsinkable ship stimulates the tourist's ability to enjoy his vacations especially being in "undiscovered waters" conceptually and literally. The cost and tourism affection is also the main issue in Low-cost Carriers (Farmaki, 2015).

In all times and in our time sunk ships around the world are a bomb for the environment. Even today the Mediterranean closed sea has several such ships laying down to the bottom and "wait" for the inevitable to happen: tons of oil leakage, plastics, and all types of pollutants. Therefore, the ship must be unsinkable for nature and the insurance company's affordable premium.

Since the available technology does not certify a $100 \%$ no sinking probability we created our patents with two main concerns:

- Obtain untouched preferential product and application rights. (Chaitidis, 2020)

- Gain affordable better insurance contract.

For the same reasons, there will more than ten patent applications shortly. Unfortunately, patents are announced only after the official filing as a general rule. We present the unsinkable vessel patent headlines here as vital for Aegean hotel and associated revitalization island actions. (zisopoulos 2020;3). The next page and figure are from the patent application and are presented in public for integration reasons.

The protection of a ship after a collision is mainly dependent on its watertight bulkheads. These bulkheads usually are vertically spread watertight wall structures within the ship to stop water in one compartment after damage in the ship's hull. In warships, these compartments are every few meters along the ship's axis line. For example, a warship of the Nimitz Class has an overall length of 300 meters and a fullload weight of 100,000 tons. The ship has 100 watertight compartments and it is practically unsinkable. Practically one compartment supports one-hundredth of the ship with 1000 ton's buoyance. With this patent, this compartment is filled with 100 big balloons and in any collision or bombing, the most will remain untouchable due to elasticity and number.

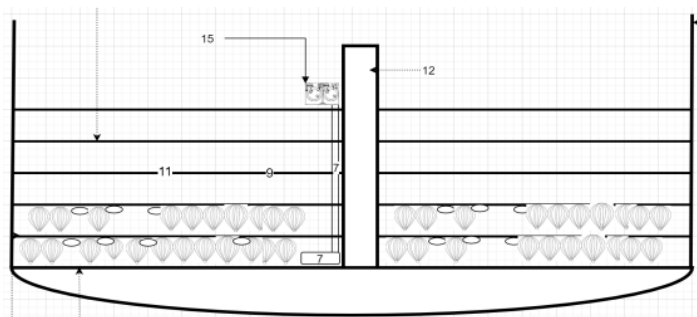


E-ISSN: 2469-6501

VOL: 7, ISSUE: 6

June/2021

http://dx.doi.org/10.33642/ijbass.v7n6p4

The patent usage is very simple. During normal travel or mooring, the waterline and hull are exactly as the original ship designer designed. When for any reason the ships start flooded the water goes everywhere and ship Buoyancy is reduced. This removal in a normal ship would lead to a total ship failure down to the sea bottom.

This does not happen with the patent. Even if the whole hull is filled with water the balloon system offers enough buoyancy to retain the ship over the sea. The result is valuable vessel retention and avoidance of sea pollution.

\subsubsection{Rigid Sailing Ship 5000 years later}

Sailing helped mankind for thousands of years. Rigid Sailing construction will be installed on the platform. For our research we design our implementation, keeping in mind our Pelasgian ancestors sailing in Aegean water for five thousand years now. Our rigid sails implementation will be:

- One size to fit all our needs from Metropolitan Vessel to the one-person coastal shuttle.

- Expandable in height and connectable in space.

- computer and manually controlled wind wing.

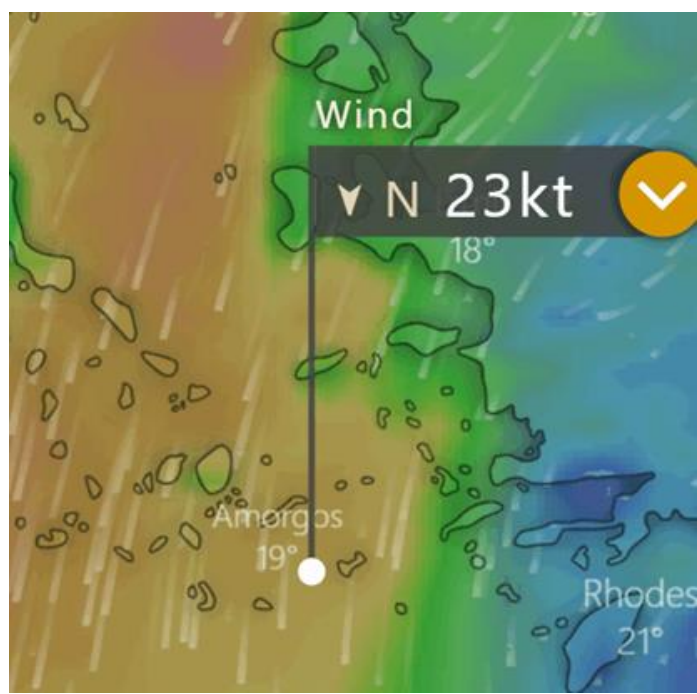

Figure 5, At 23 knots wind in the hotel area and the rigid sale ship must slow down to meet the 11 knots cruise speed.

The rigid sale ships and boats concern only the transport options. Maritime tourism is different as Diakomihalis expressed initially (2007).

\subsubsection{Modular Vessel Design}

DNA-vessel is much more than an unsinkable vessel. The ship is not an object but a modular entity with identical infrastructure, the same energetic systems, and complementing functionality rights. Layout details will be revealed after relevant patents filing in WIPO. At the current design stage pre-characteristics include:

- Any module node has the same basic survival and mechanical systems.

- Interconnection in a swarm with at least three points.

- No main ship existence.

- Variable size, propulsion schema, manning, military complementary operation, etc.

In the future unlimited type of compo-module vessels, it will be needed. Initially minimum interoperated compo vessels selection list includes six variations:

- Main compo with emphasis on ships commandment, crew and passenger live space, full around connectivity. (type 1)

- Hotel compo with luxury apartments, shopping area (type 2)

- Facilities-vital hotel Productions compo with full logistics and storage. (type 3)
- Energy-Water vessel storage facility (type 4)

- Waste management and recycling factory units for all islands in the "Metropolitan" area and beyond. (type 5)

- Empty vessel with infrastructure to be converted into anything with unlimited air-water smaller bring in and carry away modules. (type 6)

All compos are unsinkable, remote limited guidance, low speed, and full zero-emission energy compatible.

\subsubsection{Aegean Highway Modules and Skaramagas Shipyard}

The battleship of Salamis saved the ancient world from the barbarians took place a few miles away from our distributed resort hotel. In our times exactly, there is located the famous Skaramaga shipyards; seeking private capital from, modernization and suffering from politics (Spyridakis, 2006).

We evaluate now a different design. The needs for the hotel in vessels and parts are huge. The DNA vessel basic propulsion will be thousands of small hydro jets (or others) micro machines. The same electric hydro-jet will be used for all escorting and facility boats totaling up to a number that a shipyard could reopen under new technology. The Skaramagas new production line will design, test, prepare and integrate into ships-boats and vessels the following units per year:

- Modular Hydro jets; several thousand. 
- Balloons and associated systems for unsinkable ships a few million.

- Small modular Rigid sales for sailing several hundred.

- Reforestation and revitalization systems several hundred.

- Fishery, rain-water harvest system with photovoltaics, electricity system at unknown cost and units per year.

- Commercial and police heavy-duty 1000 kilograms lifting drones.
We prepare or acquire all recent patents, technology rights, and funds for factory restart and productive operation.

\subsubsection{AEGEAN low-speed Interstate highway}

At the center of the Aegean, we selected 43 points with rather big islets. Most islets will be resort apartments when a few will house supporting activities. In Mavra for example there is the wind energy center. From there the DNA vessel travels downstream according to air-speed air estimations for the rigid sail propulsion systems.

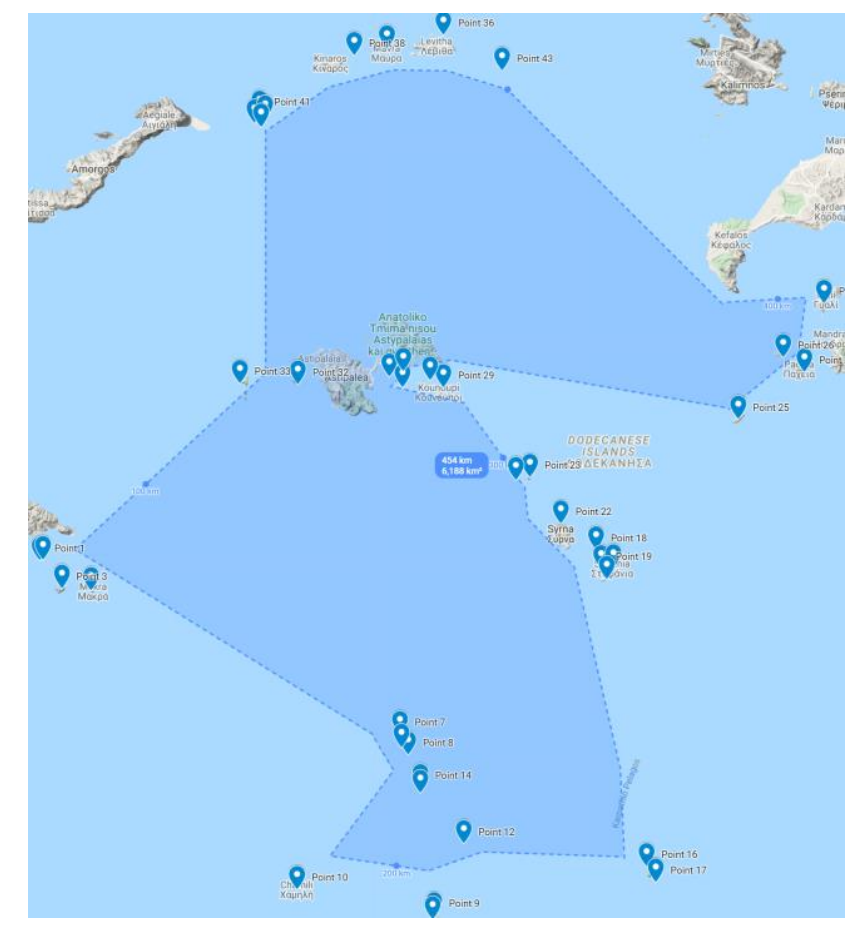

Figure 6, Deucalion-Noachian Ark round trip

DNA takes 24 hours to travel at a constant speed of 11 knots $(20 \mathrm{~km} /$ hour $)$ all around the supported 43 islets at a total distance of $454 \mathrm{~km}$. The next day it follows the same route. The route could change according to certain days with NorthSouth winds fro12 hours and South-North for the next 12 hours.

When the city-vessel reaches an island-quest-room a faster service boat detaches from the DNA approaches the island, unloads the hotel basket-container with the requested goods, loads the old basket, and a little later it embarks-docks to the mother ship. The procedure differs when an electricity module travels and locks at the vessel body.

\subsection{Islets and islands revitalization}

Restoration and revitalization in a closed landscape have a lot of meanings and actions to be proposed. Since initial restrictions are local regulations super-ecologists, like Rochford (2017) found the eco-restoration development and implementation must be inter-mixed with verification techniques, semiotic re-regulation of the environment, and a disruption of the relationship between inhabitants and the environment. In Aegean hotel resort in the foreseen future the cost remains the same as the competition. After concept approval, the cost and leisure will be increased exponentially.

Tourism Area Life Cycle (TALC) introduced by Butler (2006) is the most robust and widely used as a managerial framework and inspired the idea of this research along with the engineering implementation.

In our case, the current research selection list suggests as a general idea, Lee (2014) explored the use of sustainable tourism as a tool for the regeneration and "greening" of urban areas. Closer to the needs of the Aegean Sea and Nature-based tourism in protected areas, is Liu (2016) in his application of the TALC modeling to enhance biodiversity, poverty alleviation in sustainable development. Being on a closed isolated island our huge difference is that we generate from zero diversity and we have the luxury and responsibility to select the factors and level of influence.

\subsubsection{Land Preparation-Reforestation}

The island's valuable land leads all our restoration steps. All the noninhabitant islets have minimized land. On 
that land, all known methodologies for cultivation and regeneration will be applied. Although the task is very challenging there is the island remoteness and isolation benefit that guarantees the successful land restoration in all different desired levels. The problem of land restoration through reforestation is mainly the cost. Indicatively this problem is solved with a European Patent that combines rain-harvest, electricity, and tree growing at a cost of around 60 Euros (Gerakis, 2012) and its associated patent.

\subsubsection{Fishery production for in hotel use}

Aegean resort must produce their food. Some islands will be devoted to fishing. We do not rely on traditional nonsustainable and non-profitable fishing. New technologies for fishing and live fish delivery will be applied. One is the aquatic LCA fisher adaptation to open sea (Zisopoulos 2020;2). More technologies will be acquired and/or patents will be applied like live seafood delivery to the hotel and coastal supermarkets. All aquatic production will be stored locally in a moored compo-vessel until the mother ship passes by and collects it.

This production is not associated with sport fishing or recreational fishing attracts tourists with a lot of marketing and regulation models (Floyd, 2006; Diogo 2020). This type of fishing is not agritourism.

\subsubsection{Electricity Production}

The Mavra island is one of the noninhabitant deserted islands in the area and it has the ideal orientation to capture the regular winds in the field. On the island, some wind electricity production towers will be constructed giving Electricity at the range of GWh. There could be as many island, vessel and mother vessels as the Metropolitan Highway electricity balance requires.

\subsubsection{Rainstorm Water Harvest}

Desert and deserted islands have in common that they both cannot preserve any form of life due to waterless. During the winter months, the Aegean island rain is sufficient for any summer activity. Traditional methodologies will be used with innovative material and new patents to collect rain storm water, retain its purity, store it locally or in a moored vessel type four. For efficient cost and logistics, many islands will be devoted to rainwater collection possibly draining from photovoltaics panels. Finally, the vessel with water and electricity moors to the mother ship.

\subsubsection{Agritourism Eco productions}

Bressan (2020) proposed Sustainable-Oriented Innovation (SOI) for Agritourism in small firms. We incorporated this approach under multinational company implementation as an "Aegean resort" feature with farmproduced, organically farmed meals and products.

Many islands are big to be used as hotel rooms. On these island's various Biological plants would be cultivated and livestock Productions could be made (Vasios 2020). Standard sustainable technologies will be applied and new wait from us to be invented (Zisopoulos and Broni, 2020;1)

\section{RESULTS}

\subsection{Hotel Rooms Services}

After initial steps, all islet-room are ready to offer our hospitality. For integration reasons we practically explained 10 room-islets with the dedicated convention that utilizes the strong points of our hotel implementation. All types of rooms communicate efficiently and economically with the DNAvessel, unmanned bottle-shuttles, small boats, and of course our Intranet.

\section{Managers}

\subsubsection{Internet and Cell phone detoxification for top}

Internet and mobile phone technology are the cornerstones of business and investments with profits doubled every year. However, as with every human creation, technology raised serious problems. Crawford (2008), analyzed the arrival of social software on mobile platforms, Mahapatra (2019) defined the role of loneliness self-regulation and 'smartphone addiction' media while Conti \& Cassel (2020) set the liminality theoretic standards.

Top managers, Government officers, senators, and prime ministers when they arrive in uncharted waters they are vulnerable to mistakes or total failure. They depend too much on technology, analysis, and communications. Unfortunately, it comes a moment that technology collapses, and criminals bring them to desperation. This would cost millions and companies are ready to pay for it. The confined island is the perfect place for Internet and cell phone detox along with seaside vacations.

\subsubsection{Patients with special dietary}

Humans and patients suffer and enjoy low or dark passions regarding mostly food and alcohol but not only (Lin 2020). Sick people try very hard to alter their habits but usually are defenseless in a normal home or hotel environment. On an isolated island, the situation differs dramatically. There is no food or beverages to feed their passion no matter how much they suffer. Of course, they are wounded but they do survive for a healthier life.

\subsubsection{Pet or wildlife island}

An island will be prepared and equipped with automatic feeding and watering machines to feed pet animals (Ong, 2017). Pets are set free on the island. The happy residents in an island room enjoy the pet colony, they feed them, they love them during staying on the island. When they travel away and in winter nature, hotel workers, or automated machines feed them through to their YouTube channel.

\subsubsection{Leisure island}

Europe most famous for nightlife, clubs, illegal parties, and generally nightlife places are the Spanish Ibiza and the Greek Mykonos (Berrozpe, 2017; Serra 2017; Carr,2002; Cirer, 2020; Papatheodorou 2003). This type of leisure is for younger tourists, party animals, and no-limit clubbing. This 


\section{(C) Center for Promoting Education and Research (CPER) USA}

www.cpernet.org

type of holiday could indelible mark any resort hotel or area but not the island resort hotel. Any island full autonomous operation can adopt the desired characteristics and not acquire an evil or good stamp on it. Since area visibility in the same night different types of leisure co-exist:

- A club island lights up from dancing laser and 130decibel music.

- The next island peaceful fishers enjoy the moon night waiting with their fishing rods.

- In a few kilometer's distances' a romantic young couple snuggle in front of a beach fire giving promises of eternal love.

\subsubsection{Recreational beach fire}

Movies, video clips, jingles, camping holidays, love stories have one thing in common: the beach fire. For the islet property evaluation more suitable are hedonic pricing models. (Sirmans, 2005; Tapsuwan, 2016; Fennel, 2020). Also, Kim (2020) evaluating recreational beaches insists on fireplaces, swimming pools, scenic views, and various distances. In an islet, there is an unlimited swimming pool, extended open fireplaces, and no distances at all. This verifies our common thought that an islet with all these facilities is priceless and high priced altogether.

Movies, video clips, jingles, camping holidays, love stories have one thing in common: the beach fire. For the islet property evaluation more suitable are hedonic pricing models. Valuating recreational beaches insists on fireplaces, swimming pools, scenic views, and various distances. In an islet, there is an unlimited swimming pool, extended open fireplaces, and no distances at all. This verifies our common thought that an islet with all these facilities is priceless and high priced altogether.

\subsubsection{Casino island}

The initial idea was to formulate a casino island. The concept fits very strongly in VIP tourism, gambling stories different from traditional gambling. Scot (2003) investigated gambling stories are set within a different social space and reflect a different social morality from the stories of traditional gambling. The casino is a powerful development opportunity around the globe (Kang, 2012; Lee, 2010; Stokowski 2011). Astonishingly there is an "island casino" (Gurel, 2011) within the reach of our vessel in Izmir. With this, which is only a casino, not an island, we can interchange customers when both casino players demand a few kilometers sea cruise or a rigid continental soil under their feet.

Although the casino was our primary business intention for this room type very easily we reverse the universe and create a gambling rehabilitation area with a focus on:

- Full casino emulation but no money evolved.

- An archaic casino with primitive life earnings like food or time money.

The casino island inclines more to educational rehabilitation use. In the main vessel with thousands of inhabitants-passengers, there will be another glamorous Casino for the unrepentant rest of us chosen or fallen few.

\subsubsection{Aquaculture prisoner rehabilitation facility}

The strong security characteristics made island prisons famous. After legislative research and possibly new law regulations in our island complex prisoners accepted could be:

- Prisoners with hand or foot bracelets not eligible to use them in their homes due to serious criminal behavior.

- Prisoners not accepted in prison farms for their security, escape possibility, and the cost of all these.

- Tourists are more than prisoners obliged to a partial prison sentence.

- Prisoners-businessman running one of the resort activities.

This last contradiction reveals the secluded island concept. A person for leisure enjoys an islet while another person feels like a prisoner there.

\subsubsection{Free speech Land}

Free speech is a crucial part of Socrates's heritage and is a fragment of Platonic freedom. (Harris, 2009; German, 2017). Ward (2019) started with the importance of the Socratic reason in the Philosophy of History and proposed to flourish the freedom in the modern, liberal democratic order. Two thousand years later British empire and civilization voted the 1872 Act, giving the right to free speech in Hyde Park (Roberts 2008).

Pelasgian islands welcome Platonic Free speech back to its roots two hundred years later. The freedom of speech on a tiny island without a significant audience suffers from severe nonsense. All three internets Normal, Dark, and Galactic according to the three degrees of law enforcement possibility, could give the desired wider audience.

\subsubsection{High tech research remoteness facility in a box}

Pharmaceutical companies have been turning to global markets to conduct clinical trials with many countries in the US and Western Europe (Al Tajir, 2015). A similar methodology of research for more serious and/or dangerous cases would take place in a tiny unfrequented island. Research advantages that utilize the hotel islets are:

- The garden of Edem working environment.

- 24/7/365 devoted to research and development

- Absolute secrecy

- Total solitude without hassles from everyday social life.

- No car driving, no shopping, no delicate culinary, no bar and coffee option, no life actually as we know it.

Almost any type of research needs isolation and devotion but there are cases the islet environment is crucial for successful operation:

- National Defence secret research and development.

- New consumer product design.

- Beta test site for professional systems. 


\section{(C) Center for Promoting Education and Research (CPER) USA}

www.cpernet.org

- Multinational companies' secret meetings

The internet connection needs a sophisticated customtailored non-commercial, although not pleasant for the user, firewall, both in preventive the leakage and forensicspunishment levels. Another strong point is that pure researchers do not belong to this world, they live on their own. A desolation county would be for the perfect research-living environment.

\subsubsection{Biological screened experiments non- productive cultivation}

A different research case is agriculture and food products. An islet represents the absolute environment to test a new plant, tree, chicken, or bovine since the environment is totally clean or could be brought to zero points through a controlled total fire. Then cultivation and farm start by adding ingredients into the production line: plants, animals, chemical additives, water, etc. All actions and ingredients are recording in remote systems. To increase efficiency all cultivation is executed by intelligent machinery (Zisopoulos 2018).

\subsection{Sovereignty options}

The realization of all the above developments after extensive research could be a complicated contract with the Hellenic Authorities to research, patent, study, construct and operate profitably the island complex. Free speech room-island seems like a harmful philosophical conversation place. Although the start-up mode is a 2000-room resort hotel there are two more operational modes to be investigated:

- To resemble all municipality operations and services

- To evolve into a sovereign state entity inside the Hellenic state retaining the sea flexible legislation.

\subsection{Monumental Design}

A few miles from here Stoic Cleanthes syllogism was "If a city is an inhabited construction to which people may have recourse for the dispensation of justice, then a city is surely refined. But a city is that sort of habitation. So, a city is refined." (Linzei, 2003; Harward 1930). The dominant strong idea, the DNA-vessel overall layout must follow the monumental design of local history for the past thousands of years and also be here until the next millennium. We predict that this would be the hottest international architectural design contest of this decade. (Morris, 1978; Gurel, 2011) possibly under the context title "monumental design in the multi-level Sustainability Era" (Crespi, 2019)

\subsection{Pandemic Compliance}

Philosopher, Slavoj Žižek (2020) provided a concise and provocative snapshot of the crisis as it widens, engulfing us all. We respect the humoristic opinion of a game-changer for travel and tourism, a more ethical, responsible, and sustainable tourism but we disagree with that the world as we knew it has stopped turning. The earth keeps on turning around itself and the world shutdown has been defined along before not from a Slovenian but an Aegean in Apocalypse. Our compliance to his Covid-19 opinion is minimized to the fact that island-resort is by definition responsible and sustainable and ethics primarily due to quarantine isolation and organization. Gössling (2020) elevates COVID-19 as an analog to the ongoing climate crisis and the demands advocation by UNWTO, ICAO, CLIA, WTTC, and other tourism organizations. We believe that all these organizations need to evolve in something less bureaucratic and support tourism innovation like our Aegean resort. Pandemic is a change for progression in any layer of international tourism including proposals like Aegean resort hotel islets.

\subsection{TALC modelling}

Yun (2017) and Javed (2020) investigated the role of government in tourism based on TALC modeling (Tourism Area Life Cycle). Although research is more than current it is already old-fashioned due to new underlying economic proceeds like QFS (Tsiatsiou, 2020). The time-series data are accurate but misleading because "times are changing" according to an old and current singer with a Nobel prize (Stromberg, 2018). Of course, the Nobel was in poetry but our definition of tourism is closer to leisure, fine arts, and myths than frozen cold management, misunderstood sustainability, and "abdominal" money investments.

\section{Discussion}

We do apologize for some exaggerated opinions, phrases, and overall verbiage writing without serious thinking. The only reason for such sentiment writing for a serious one billion exploratory investment study is the need to amalgamate different things in a readable motion generator schema. There are heterogeneous clauses like serious funding options, innovative finance, sustainable tourism, regeneration engineering. Most of all we want to feel the festive leisure nature of tourism. Tourists work eleven tedium months to live their dream in Greece and our research must conclude and include in our hotel all their dreams and leisure fantasies.

The project's preliminary skeptical steps are strengthened only through sustainable engineering. The next steps will be based on engineering only: Environmental engineering, financial engineering, insurance swaps, invention patents, transport, and shipyard engineering. Specific steps, future Developments, and technologies to be evaluated will be:

- A private beach of 100 meters could raise the number of quests to more than two hundred thousand.

- Various islands will be assigned to local or multinational hotel monopolies to their standards.

- Metropolitan Aquatic Environment Universal Municipality services range from garbage collection and mail delivery to elections and national defense military conscription.

-Aquatic Sovereign Public services; There are is no space for contestation for the two sovereignty types in Greece today. The Hellenic government and the European Community long-hand. We believe that offshore banking ended for our galaxy. 
- Quantum Financial System; With QFS we bypass the deposit reefs with posit only digital money.

- Insurance risk calculation possibly through parametric insurance.

The only drawback that Aegean Metropolitan Resort has is its extremely high cost. We face the same complaint with the USA space program, global warming cost, and insurance expenditure. All of our development is proven to be valuable for life on earth as we know it. We believe that we do not cash out this high cost in money but we pay with the life and progression of our children.

\section{Acknowledgments}

The corresponding author expresses her thanks to Liechtenstein's top financial analysts for their precious contribution in his first exciting steps to Mathematics and Engineering.

\section{Declaration of interest statement}

All authors do confirm that there are no relevant financial or non-financial competing interests to report.

\section{Funding}

This manuscript was an interim study through a Ph.D. study, funded through the University of Western Macedonia. The authors received no direct funding for this research.

\section{References}

AAl Tajir, G., \& Al-Rawi, Y. (2015). The Middle East-North Africa Region: A Cocoon for Clinical Trials. Accountability in Research, 22(4), 201-204. doi:10.1080/08989621.2015.1015835

Amoamo, M. (2011). Remoteness and myth making: tourism development on Pitcairn Island. Tourism Planning \& Development, $8(1), 1-19$.

Araña, J. E., \& León, C. J. (2016). Are tourists animal spirits? Evidence from a field experiment exploring the use of non-market based interventions advocating sustainable tourism. Journal of Sustainable Tourism, 24(3), 430-445. doi:10.1080/09669582.2015.1101128

Ateljevic, I. (2020). Transforming the (tourism) world for good and (re)generating the potential 'new normal'. Tourism Geographies, 22(3), 467-475. doi:10.1080/14616688.2020.1759134

Berrozpe, A., Campo, S., \& Yagüe, M. J. (2017). Understanding the identity of Ibiza, Spain. Journal of Travel \& Tourism Marketing, 34(8), 1033-1046.

Bressan A. \& Matteo Pedrini (2020) Exploring Sustainable-Oriented Innovation within Micro and Small Tourism Firms, Tourism Planning \& Development, 17:5, 497-514, DOI: 10.1080/21568316.2019.1673810

Brockway, G. P. (1998). Path dependency and animal spirits. Journal of Post Keynesian Economics, 21(1), 163-165.

Bruwer J. \& Lesschaeve I. (2012) Sources of Information Used by Tourists Travelling to Visit Canadian Winery Tasting Rooms, Tourism Planning \& Development, 9:3, 269-289, DOI: 10.1080/21568316.2012.672452

Butler, R. (Ed.). (2006). The tourism area life cycle (Vol. 1). Channel view publications.

Caffyn, A., \& Jobbins, G. (2003). Governance Capacity and Stakeholder Interactions in the Development and Management of Coastal Tourism: Examples from Morocco and Tunisia. Journal of Sustainable Tourism, 11(2-3), 224-245.

doi:10.1080/09669580308667204

Carr, N. (2002). Going with the flow: An assessment of the relationship between young people's leisure and holiday behaviour. Tourism Geographies, 4(2), 115-134. doi:10.1080/14616680210124891

Chaitidis George, Athanasios Zisopoulos, "Invention Patents and Competitive Tendering, a balance between PCT Office, Trade Bureau of Competition, procurement agencies and municipalities in a Public call for offers", Journal of Business and Economics, ISSN 2155-7950, USA March 2020, Volume 10, No. 12, pp. 1-16

Cirer-Costa, J. C. (2020). Economic and social resilience accounts for the recovery of Ibiza's tourism sector. Tourism Geographies, 1-22. doi:10.1080/14616688.2020.1722214

Ciruelos, G. (2018). What is the Roundest Country? Math Horizons, 26(3), 26-27. doi:10.1080/10724117.2018.1524089

Coastial, (2012) "Coastal and Marine Ecosystems - Marine Jurisdictions: Coastline length". World Resources Institute. Archived from the original on 2012-04-19. , Retrieved January 8, 2021,from

https://web.archive.org/web/20120419075053/http://earthtrends.wri.org/text/coastal-marine/variable-61.html

Cochrane Janet (2015) Romancing the Wild: Cultural Dimensions of Ecotourism, Tourism Planning \& Development, 12:4, 497 499, DOI: $10.1080 / 21568316.2015 .1073499$ 


\section{(C) Center for Promoting Education and Research (CPER) USA}

www.cpernet.org

Conti, E., \& Heldt Cassel, S. (2020). Liminality in nature-based tourism experiences as mediated through social media. Tourism Geographies, 22(2), 413-432. doi:10.1080/14616688.2019.1648544

Crawford, A. (2008). Taking Social Software to the Streets: Mobile Cocooning and the (An-)Erotic City. Journal of Urban Technology, 15(3), 79-97. doi:10.1080/10630730802677970

Crespi-Vallbona, M., \& Smith, S. G. (2019). Managing sociocultural sustainability in public heritage spaces. Tourism Planning \& Development, 1-19.

Diakomihalis M. (2007) The Impact of Maritime Tourism on the Greek Economy via the Tourism Satellite Account, Tourism and Hospitality Planning \& Development, 4:3, 231-244, DOI: 10.1080/14790530701783640

Dickinson, J. E., Filimonau, V., Cherrett, T., Davies, N., Norgate, S., Speed, C., \& Winstanley, C. (2013). Understanding temporal rhythms and travel behaviour at destinations: potential ways to achieve more sustainable travel. Journal of Sustainable Tourism, 21(7), 1070-1090. doi:10.1080/09669582.2013.802328

Diogo, H., Veiga, P., Pita, C., Sousa, A., Lima, D., Pereira, J. G., ... \& Rangel, M. (2020). Marine Recreational Fishing in Portugal: Current Knowledge, Challenges, and Future Perspectives. Reviews in Fisheries Science \& Aquaculture, 28(4), 536-560.

Duval, D. T. (2013). Critical Issues in Air Transport and Tourism. Tourism Geographies, 15(3), 494-510. doi:10.1080/14616688.2012.675581

Eijgelaar, E., Nawijn, J., Barten, C., Okuhn, L., \& Dijkstra, L. (2016). Consumer attitudes and preferences on holiday carbon footprint information in the Netherlands. Journal of Sustainable Tourism, 24(3), 398-411. doi:10.1080/09669582.2015.1101129

Emmons, C. (2017). Bridges 2016 poetry anthology. Journal of Mathematics and the Arts, 11(1), 62-66. doi:10.1080/17513472.2016.1264263

Farmaki Anna \& Andreas Papatheodorou (2015) Stakeholder Perceptions of the Role of Low-cost Carriers in Insular Tourism Destinations: The Case of Cyprus, Tourism Planning \& Development, 12:4, 412-432, DOI: 10.1080/21568316.2015.1013566

Feng, Z. (2010). A Review of "Tourism and Transport: Modes, Networks and Flows". Tourism Geographies, 12(4), 579-582. doi:10.1080/14616688.2010.516767

Fennell, D. A. (2020). Technology and the sustainable tourist in the new age of disruption. Journal of Sustainable Tourism, 1-7. doi:10.1080/09669582.2020.1769639

Floyd, M. F., Nicholas, L., Lee, I., Lee, J. H., \& Scott, D. (2006). Social stratification in recreational fishing participation: Research and policy implications. Leisure Sciences, 28(4), 351-368.

Focus On, 2017, 100 Most Popular 1990s Science Fiction Films, 1st edition (December 12, 2017),

Freksa, C., Barkowsky, T., Falomir, Z., \& van de Ven, J. (2019). Geometric problem solving with strings and pins. Spatial Cognition \& Computation, 19(1), 46-68. doi:10.1080/13875868.2018.1531415

García Romero, F. (2013). Sports tourism in Ancient Greece. Journal of Tourism History, 5(2), 146-160. doi:10.1080/1755182X.2013.828784

Gembillo, G. (2007). Analogy Between the Theorem of Pythagoras and the Relations of Uncertainty of Heisenberg. World Futures, 63(1), 38-41. doi:10.1080/02604020600948958

Georgios Gerakis, Kostas Spinthiropoulos, Athanasios Zisopoulos, (2019), MAGDALâ Trader Workstation conceptual definition of selected features; Realistic Financial Time Series, Byzantine Time, temporospatial, Data Science Analytics, and GDPR aspects.,International Symposium on Ambient Intelligence and Embedded Systems,,Coimbra, Portugal,11 - 14 September, 2019 ,

Gerakis, G. and Zisopoulos, D.,(2012), Cretan integrated dual mode Resort University, International Conference on Tourism 2012, Archans, Crete, 23rd - 26th May 2012

German, A. (2017). Is Socrates free? The Theaetetus as case study. British Journal for the History of Philosophy, 25(4), 621-641.

Gössling, S., Scott, D., \& Hall, C. M. (2020). Pandemics, tourism and global change: a rapid assessment of COVID-19. Journal of Sustainable Tourism, 1-20.

Gren Martin \& Edward H. Huijbens (2014) Tourism and the Anthropocene, Scandinavian Journal of Hospitality and Tourism, 14:1, 6-22, DOI: 10.1080/15022250.2014.886100

Gürel, M. Ö. (2011). Architectural mimicry, spaces of modernity: the Island Casino, Izmir, Turkey. The Journal of Architecture, $16(2), 165-190$.

Gurell, B. (2011). A conceptual method for data integration in business analytics (Doctoral dissertation, uniwien). 


\section{(C) Center for Promoting Education and Research (CPER) USA}

www.cpernet.org

Hall, C. M. (2013). Framing behavioural approaches to understanding and governing sustainable tourism consumption: beyond neoliberalism, "nudging" and "green growth"? Journal of Sustainable Tourism, 21(7), 1091-1109. doi:10.1080/09669582.2013.815764

Hall, C. M. (2016). Intervening in academic interventions: framing social marketing's potential for successful sustainable tourism behavioural change. Journal of Sustainable Tourism, 24(3), 350-375. doi:10.1080/09669582.2015.1088861

Harris, R. (2009). Freedom of speech and philosophy of education. British Journal of Educational Studies, 57(2), 111-126.

Harward, J. (1930). The early stoics. The Australasian Journal of Psychology and Philosophy, 8(4), 271-289. DOI: $10.1080 / 00048403008541329$

Higham, J., Cohen, S. A., Peeters, P., \& Gössling, S. (2013). Psychological and behavioural approaches to understanding and governing sustainable mobility. Journal of Sustainable Tourism, 21(7), 949-967. doi:10.1080/09669582.2013.828733

Hopkins, D. (2020). Sustainable mobility at the interface of transport and tourism. Journal of Sustainable Tourism, 28(2), 129-143. doi:10.1080/09669582.2019.1691800

Jarratt, D., \& Davies, N. J. (2020). Planning for climate change impacts: coastal tourism destination resilience policies. Tourism Planning \& Development, 17(4), 423-440.

Javed, M., \& Tučková, Z. (2020). The role of government in tourism competitiveness and tourism area life cycle model. Asia Pacific Journal of Tourism Research, 25(9), 997-1011.

Kang, K. H., Lee, S., Choi, K., \& Lee, K. (2012). Geographical Diversification, Risk and Firm Performance of US Casinos. Tourism Geographies, 14(1), 117-146. doi:10.1080/14616688.2011.593043

Kantenbacher, J., Hanna, P., Miller, G., Scarles, C., \& Yang, J. (2019). Consumer priorities: what would people sacrifice in order to fly on holidays? Journal of Sustainable Tourism, 27(2), 207-222. doi:10.1080/09669582.2017.1409230

Kim, J., Yoon, S., Yang, E., \& Thapa, B. (2020). Valuing Recreational Beaches: A Spatial Hedonic Pricing Approach. Coastal Management, 48(2), 118-141.

Kowalski, J. M. (2012). Navigation et géographie dans l'Antiquité gréco-romaine: la terre vue de la mer (p. 197). Paris: Picard.

Lee, C.-K., Kang, S., \& Reisinger, Y. (2010). Community Attachment in Two Rural Gaming Communities: Comparisons between Colorado Gaming Communities, USA and Gangwon Gaming Communities, South Korea. Tourism Geographies, 12(1), 140168. doi:10.1080/14616680903493688

Lee, Y. K., Lee, C. K., Choi, J., Yoon, S. M., \& Hart, R. J. (2014). Tourism's role in urban regeneration: examining the impact of environmental cues on emotion, satisfaction, loyalty, and support for Seoul's revitalized Cheonggyecheon stream district. Journal of Sustainable Tourism, 22(5), 726-749.

Le-Klähn, D.-T., Roosen, J., Gerike, R., \& Hall, C. M. (2015). Factors affecting tourists' public transport use and areas visited at destinations. Tourism Geographies, 17(5), 738-757. doi:10.1080/14616688.2015.1084527

Lin Jiayi, Qingming Cui, Honggang Xu \& Jaume Guia (2020) Health and local food consumption in cross-cultural tourism mobility: an assemblage approach, Tourism Geographies, DOI: 10.1080/14616688.2020.1867887

Linzey, M. (2003). Corporate Relations in the Hellenistic Polis. Journal of Architectural Education, 56(4), 57-63.

Liu, W., Vogt, C. A., Lupi, F., He, G., Ouyang, Z., \& Liu, J. (2016). Evolution of tourism in a flagship protected area of China. Journal of Sustainable Tourism, 24(2), 203-226.

MacCannell, D. (2012). On the ethical stake in tourism research. Tourism Geographies, 14(1), 183-194, DOI: $10.1080 / 14616688.2012 .639387$

Mahapatra, S. (2019). Smartphone addiction and associated consequences: role of loneliness and self-regulation. Behaviour \& Information Technology, 38(8), 833-844. doi:10.1080/0144929X.2018.1560499

Melissen, F., \& Koens, K. (2016). Adding researchers' behaviour to the research agenda: bridging the science-policy gap in sustainable tourism mobility. Journal of Sustainable Tourism, 24(3), 335-349. doi:10.1080/09669582.2015.1071384

Meyer-Arendt Klaus (2018) Tourism Geographies: geographic research on coastal tourism, Tourism Geographies, 20:2, 358363, DOI: 10.1080/14616688.2018.1434815

Mijuskovic, B. (1981). Loneliness and human nature. Psychological Perspectives, 12(1), 69-77. doi:10.1080/00332928108408679

Morgan, N., \& Pritchard, A. (2018). Gender, advertising and ethics: Marketing Cuba. Tourism Planning \& Development, 15(3), 329-346.

Morris, E. K. (1978). Symbols of empire: architectural style and the government offices competition. Journal of Architectural Education, 32(2), 8-13. 


\section{(C) Center for Promoting Education and Research (CPER) USA}

www.cpernet.org

Nilsson, M., \& Blom, T. (2018). Finisterre: being and becoming a myth-related tourist destination. Leisure Studies, 37(4), 359-370. doi:10.1080/02614367.2018.1476904

Nyaupane Gyan \& Netra Chhetri (2009) Vulnerability to Climate Change of Nature-Based Tourism in the Nepalese Himalayas, Tourism Geographies, 11:1, 95-119, DOI: 10.1080/14616680802643359

Ong, C.-E. (2017). 'Cuteifying' spaces and staging marine animals for Chinese middle-class consumption. Tourism Geographies, 19(2), 188-207. doi:10.1080/14616688.2016.1196237

Papalas Antony Hohn (2013) Navigation et géographie dans l'antiquité greco-romaine, The Mariner's Mirror, 99:3, 351-352, DOI: $10.1080 / 00253359.2013 .785157$

Papatheodorou, A. (2003). Corporate strategies of British tour -operators in the Mediterranean region: An economic geography approach. Tourism Geographies, 5(3), 280-304. doi:10.1080/14616680309713

Peeters, P. M. (2013). Developing a long-term global tourism transport model using a behavioural approach: implications for sustainable tourism policy making. Journal of Sustainable Tourism, 21(7), 1049-1069. doi:10.1080/09669582.2013.828732

Ram, Y., Nawijn, J., \& Peeters, P. M. (2013). Happiness and limits to sustainable tourism mobility: a new conceptual model. Journal of Sustainable Tourism, 21(7), 1017-1035. doi:10.1080/09669582.2013.826233

Reynolds, K. (1995). Waterworld [Motion picture]. United States: Davis Entertainment, Gordon Company, Licht/Mueller Film Corporation, Universal Pictures.

Roberts, J. M. (2008). Expressive free speech, the state and the public sphere: A Bakhtinian-Deleuzian analysis of 'public address' at Hyde Park. Social Movement Studies, 7(2), 101-119.

Rochford, F. (2017). Designing the environment-the paradox of eco-restoration. Griffith Law Review, 26(2), $202-220$.

Romero Fernando García (2013) Sports tourism in Ancient Greece, Journal of Tourism History, 5:2, 146-160, DOI: 10.1080/1755182X.2013.828784

Rudden, M. G. (2011). The 'secret cocoon': Fantasies about the private self in the absence of consensual reality. The International Journal of Psychoanalysis, 92(2), 359-376. doi:10.1111/j.1745-8315.2011.00406.x

Rutty, M., \& Scott, D. (2010). Will the Mediterranean become "too hot" for tourism? A reassessment. Tourism and Hospitality Planning \& Development, 7(3), 267-281.

Sailing heaven, (2021), How many Greek islands are there Sailing Heaven. (n.d.). Retrieved January 6, 2021, from https://sailingheaven.com/information/how-many-greek-islands-are-there/

Sammler, K. G. (2020). The rising politics of sea level: demarcating territory in a vertically relative world. Territory, Politics, Governance, 8(5), 604-620. doi:10.1080/21622671.2019.1632219

Scheyvens, R., \& Momsen, J. (2008). Tourism in Small Island States: From Vulnerability to Strengths. Journal of Sustainable Tourism, 16(5), 491-510. doi:10.1080/09669580802159586

Schinas Margaritis, (2019), ANSWERS TO THE EUROPEAN PARLIAMENT, QUESTIONNAIRE TO THE COMMISSIONER-DESIGNATE, retrieved October 26, 2020 from https://ec.europa.eu/commission/commissioners/20192024/schinas_en

Scott, J. E. (2003). Coffee Shop Meets Casino: Cultural Responses to Casino Tourism in Northern Cyprus. Journal of Sustainable Tourism, 11(2-3), 266-279. doi:10.1080/09669580308667206

Sedgwick, H. A., \& Gillam, B. (2017). A Non-Modular Approach to Visual Space Perception. Ecological Psychology, 29(2), $72-$ 94.

Serra-Cantallops, A., \& Ramon-Cardona, J. (2017). Host community resignation to nightclub tourism. Current Issues in Tourism, 20(6), 566-579.

Siegel, P. E., Hofman, C. L., Bérard, B., Murphy, R., Hung, J. U., Rojas, R. V., \& White, C. (2013). Confronting Caribbean heritage in an archipelago of diversity: Politics, stakeholders, climate change, natural disasters, tourism, and development. Journal of Field Archaeology, 38(4), 376-390. doi:10.1179/0093469013Z.00000000066

Sirmans, S., Macpherson, D., \& Zietz, E. (2005). The Composition of Hedonic Pricing Models. Journal of Real Estate Literature, 13(1), 1-44. doi:10.1080/10835547.2005.12090154

Smith, A., Robbins, D., \& Dickinson, J. E. (2019). Defining sustainable transport in rural tourism: experiences from the New Forest. Journal of Sustainable Tourism, 27(2), 258-275. doi:10.1080/09669582.2017.1401633

Spyridakis, M. (2006). The political economy of labor relations in the context of Greek Shipbuilding: An Ethnographic Account. History and Anthropology, 17(2), 153-170. 
Steiner, J. (2018). Time and the Garden of Eden illusion. The International Journal of Psychoanalysis, 99(6), 1274-1287

Stevenson N. (2013) The Complexities of Tourism and Regeneration: the Case of the 2012 Olympic Games, Tourism Planning \& Development, 10:1, 1-16, DOI: 10.1080/21568316.2012.723038

Stokowski, P. A. (2011). The Smile Index: Symbolizing People and Place in Colorado's Casino Gaming Towns. Tourism Geographies, 13(1), 21-44. doi:10.1080/14616688.2010.529933

Stromberg, L. (2018). " Inside the Gates of Eden": Bob Dylan and The Nobel Prize. The Hopkins Review, 11(2), $266-272$.

Tapsuwan, S., \& Polyakov, M. (2016). Correctly Specifying Environmental Assets in Spatial Hedonic Pricing Models. Society \& Natural Resources, 29(2), 233-249. doi:10.1080/08941920.2015.1024808

Tomej, K., \& Liburd, J. J. (2020). Sustainable accessibility in rural destinations: a public transport network approach. Journal of Sustainable Tourism, 28(2), 222-239. doi:10.1080/09669582.2019.1607359

Tsiatsiou, E., Zisopoulos, A., Spinthiropoulos, K., \& Georganakis, P. (2020). ELECTRUM-G, A Tangible Coin Actualization Schema: Patents for Casting, Forensics and Trade Options. Business and Economic Research, 10(1), 182-195.

United Nations Conference of Trade and Development, (2020), Merchant fleet by country of beneficial ownership, annual, 2014 2020 Table summary, , retrieved August 6, 2020 from

https://unctadstat.unctad.org/wds/TableViewer/tableView.aspx?ReportId=80100

UNWTO-UNEP-WMO, C. C. (2008). Tourism: Responding to Global Challenges. UNWTO: Madrid, Spain.

Vasios, G. K., Antoniadis, I., Zevgolis, Y., Giaginis, C., \& Troumbis, A. Y. (2020). Turning a Problem into an Opportunity Through Tourism and Marketing: The Case of Wild Rabbits in Lemnos Island, Greece. In Strategic Innovative Marketing and Tourism (pp. 677-686). Springer, Cham.

Wakelin-King, G. A., \& Webb, J. A. (2020). Origin, geomorphology and geoheritage potential of Australia's longest coastal cliff lines. Australian Journal of Earth Sciences, 67(5), 649-661. doi:10.1080/08120099.2020.1742202

Ward, A. (2019). Socrates, Democracy, and the End of History. The European Legacy, 24(7-8), 695-709.

Yun, H. J., \& Zhang, X. (2017). Cultural conservation and tourism development in the consolidation stage of the tourism area life cycle model. Tourism Planning \& Development, 14(3), 353-368.

Zisopoulos A, Zisopoulou V., (2018), “ A Micro Targeted, Trainable, Modular, Multipurpose System for Agriculture Work”, patent Gr2003127y. DOI 10.6084/m9.figshare.13107998.v1

Zisopoulos A, Broni G, (2020,2)Water Recirculation Aquaculture Platform using "Life Cycle Assessment" rules and Monitoring for Insurance redefinition", patent GR20200100530. DOI 10.6084/m9.figshare.13108004.v1

Zisopoulos A, Broni G, (2020,1), “Airborne self-regulating Beehive with Big Data bio-monitor”, patent GR20200100531. DOI 10.6084/m9.figshare.13108007.v1

Zisopoulos A. , (2020,3), Unsinkable vessel through unlimited watertight bulkheads with serviceable balloons for sustainability and insurance efficiency, GR20200100652, WIPO-OBI invention patent, 28/10/2020 DOI 10.6084/m9.figshare.13201094

Zizek, S. (2020). PANDEMIC!: Covid-19 Shakes the World. John Wiley \& Sons. 